\title{
One Woman, Two Marriages: Angelou's Treatment of the Subject of Marriage in Her Autobiographies
}

\author{
Uriah S. Tetteh \\ Senior Lecturer, Dept. of Liberal Studies \\ Box AD 50, Cape Coast Polytechnic \\ Cape Coast, GHANA \\ ustetteh@yahoo.co.uk
}

\author{
Cynthia Derx-Techie \\ Lecturer, Dept. of Liberal Studies \\ Box AD 50, Cape Coast Polytechnic \\ Cape Coast, GHANA \\ Cynthiaderx477@gmail.com
}

\begin{abstract}
Maya Angelou has written seven (7) autobiographical narratives all of which critically explore all the defining phases of her experience as an African-American woman. She carefully narrates her life story in every minute detail that she remembers right from infancy to adulthood. In these collections, she recounts the ups and downs of her life. Throughout her life, she got involved in two marriages. She vividly recounts the bitter and sweet times of these marriages. This study, therefore, discusses how Angelou developed the subject of marriage touching on her marriage to Tosh Angelos and Vusumzi (Vusi) Make. Through these marriages, she learns so much about the human experience and life, in general. The study critically explores these two marriages highlighting the way and manner she endures all the challenges that erupt in them. The study concludes that Angelou emerges as a far better person than she was before contracting these marriages. Again, the conclusion drawn is that she is successful in her treatment of the subject to define her unique identity as an African American woman in a predominantly male-dominated world and so serve as an example for emerging women writers.
\end{abstract}

Keywords: marriage, Angelou, autobiography, husbands, Tosh Angelos, Vusi Make.

\section{INTRODUCTION}

After many years of slavery experience, the former slaves in America began rediscovering themselves after losing their real identity. It has been explained by many scholars that this is because most of them were even given different names so as to cut all links they had to their ancestry and roots. Baker Jnr. (1987) complements that assertion when he explained that when slavery was abolished in the latter part of the nineteenth century on the American soil, many African-Americans still had no identity created by themselves. As such, many of the descendants of these former slaves resorted to using different means to define an identity for themselves. Many resorted to working hard in many disciplines to define an identity for themselves. These include education, law, sports, politics, and a host of others.

On the social front, many African American women made a difference in the way they managed their homes and communities. With the increase in the number of men who were getting imprisoned or dying through gang violence, or running off with other women, many women were left with no choice than to bring up their children single-handedly without any support.

Maya Angelou grew up in an American society that was undergoing change by way of civil rights, racism, masculine patriarchy and domination. As such, her worldview was largely influenced by the changing trends of the time. It is therefore not surprising that her writings and works depict issues that revolve round trending issues of her formative years. Angelou has a sequel of seven autobiographies, which reveal her life story to any reader interested in knowing about her life. These novels include $I$ Know why the Caged Bird Sings(1970), Gather Together in My Name (1974), Singin' and Swingin' and Gettin' Merry like Christmas(1976), The Heart of a Woman(1981),All God's Children Need Traveling Shoes(1986), A Song Flung up to Heaven(2000), and Mom \& Me \& Mom (2012). All of these six novels critically document Maya Angelou's strive to achieve and make an impression in life as an independent woman and mother, and finally, and most importantly, as a respectable African American. 


\subsection{The Concept of Autobiography}

The concept of autobiography will be the foundation on which the study will be explored. The concept of autobiography has proven to be a very interesting area of study; yet, it can be extremely confusing in its analytical approach. It is quite complex for one to fully explain the concept because, as it were, it has no standard or structured form (Lejeune, 1989). The difficulty in analyzing autobiography as a rare but complex genre is given much credence by Olney (1980) when he postulates that "there are no rules or formal requirements binding the prospective autobiographer ... no obligatory observances gradually shaped out of a lay developing tradition" (p3).

It is interesting to note that different definitions have been offered to explain the concept of autobiography by many scholars. The study will highlight a few of these definitions. Olney (1980) in his book Autobiography Essays, Theoretical and Critical explains that though everyone knows what autobiography is, it is a fact that no two observers of a particular issue may be able to tell about that same issue in the same way. In this regard, Olney punches at the very heart of the confusion arising out of the complexity of the genre of autobiography. This study agrees with the philosophical approach adopted by Olney because where there are two observers of an issue, they cannot present the story line in much the same way as one would expect. Olney adds to this explanation that the autobiography stands for or represents something made out of someone else's life. To be more specific, Olney explains that the autobiography is “... a fascination with the self and its profound, its endless mysteries and, accompanying that fascination, an anxiety about the self, an anxiety about the dimness and the vulnerability of that entity that no one has ever seen or touched or tasted" (p23).

There are also writers like Fowlie (1988) and Freeman (1993) who share similar viewpoints about what the autobiography is. They both agree that when a person recounts his own past and the present and future aspirations in writing form, an autobiography comes into being. In effect, it is an account of one's own life story. The autobiographies of Angelou give a vivid account of Angelou's life as a child, a mother and a married woman. It is thus very clear why Angelou uses the first person pronoun to present her emotions and experiences first hand to her readers to not only entertain them but to educate them about life's ups and downs as well.

Lejeune (1989) and Egan (1999) expounded that the whole concept of autobiography gets confusing when a critical analysis is made about what is real and what is fantasy in autobiography. Ideally, because the narrator is the only person who personally goes through the experiences he narrates, no one dares challenge him or her when he or she pontificates something related to his narrator (Carr, 1986). There are times when one could question the authenticity of a particular event that the narrator is putting across, but one needs enough grounds to do so (Pascal, 1960). Despite the controversies surrounding the autobiography as a genre of literature, it still holds ground as an interesting area of study.

\subsection{Purpose of the Study}

This research has the following as its purpose:

- To explain Angelou's treatment of the subject of marriage to define her understanding of identity.

- To show how successful Angelou was in using the subject of marriage to define her identity as an African American woman.

\section{RELATED LITERATURE}

The subject of marriage in Angelou's autobiographies is another area that has attracted some critical comments. In all the seven volumes, Angelou records her experiences of marriage with two men: Tosh Angelos and Vusi Make. These two men play very important roles in the life of Angelou. One writer Bloom (1999) explains that at the time Angelou meets her first husband Tosh Angelos, she wanted a husband who will help bring up her son. Bloom links motherly love to the discussion on marriage by explaining that it is not for economic or any selfish reasons that Angelou agrees to marry Tosh but for the sake of Guy who needs a father's presence, love and care to enable him grow into a responsible and mentally balanced adult. Bloom is suggesting here that Angelou necessar ily does not have to marry Tosh but for the love that she has for her son.

Elliot (1989) reveals in Conversations with Maya Angelou that getting married is for Angelou a ticket to a never-to-attain independence. Elliot points out that Angelou's response to the question of why she gets married is that she initially thought that she could gain independence that she had long sought 
after. This revelation goes contrary to the argument of Bloom about the reason for Angelou's decision to marry Tosh, her first husband. However, one would wonder what kind of independence Angelou is referring to since she does not explain further. On Angelou's movement from one marriage to another, Neubauer (1983) re-echoes what Angelou asserts in her interview with Elliot. Neubauer explains that the movement of Angelou from one marriage to another signifies inadequacy and search for independence and freedom. This view explains the fact that Angelou does not achieve the independence she sought to gain during her marriage with Tosh Angelos and Vusi Make. Thisstudy agrees with Neubauer in this area of discussion, even though it agrees also with Bloom's contrary argument as well. As it would be recalled, Bloom links Guy, Angelou's only son to the reason why Angelou gets married to show her motherly love to him. After her second marriage breaks down, Angelou realizes that her dream of finding independence and freedom in marriage becomes a mirage. It is, therefore, not surprising that she turns her focus to find that independence and freedom in developing a career in which she finds pleasure in for herself.

In a related argument advanced by Vermillion (1992), readers get enlightened about one of the reasons why Angelou does not attain independence and freedom in her two marriages. Even though Elliot (1989) and Neubauer (1983) mention the fact that Angelou never attains the independence and freedom she hopes to gain from her marriage, a point this study agrees totally with, they do not categorically explain some of the reasons why this much-sought-after independence and freedom become unattainable. However, Vermillion (1992) points out one saying that the marriage with Tosh Angelos become a stumbling block between Angelou and the Black church, the only community of friends that Angelou knows from her childhood days growing up at Stamps, Arkansas. As it would be recalled, Angelou is brought up by Momma Henderson, her paternal grandmother who insists that Angelou frequents and develops her fellowship at the Black church. When Angelou gets married to Tosh Angelos, her first husband, who is an atheist, he bars her from fellowshipping with members of the Black church. Vermillion sites this instance as one of the reasons why Angelou's much-soughtafter independence and freedom become a mirage. This study believes that the break-down of Angelou's first marriage can be firmly attributed to Tosh Angelo's atheist stance of preventing Angel ou's fellowship with members of the Black church.

Abel (1981) explains the importance of church and friendship in the life of African-American women. Abel sees the Black church, an institution that most young Blacks are introduced to by their parents or guardians, as fertile grounds for growing friendship and communal linkages between members of the Black community. Abel does not see reason in why a husband should prevent his wife from fraternizing with the Black community in the Black church since in her estimation the Black church symbolizes an ideal place where most African-Americans could identify themselves with their fellow Black neighbours.

Adding a different twist to the issues discussed so far under the subject of marriage, Lupton (1990) in her book Maya Angelou: A Critical Companion discusses the role fantasy plays in the marriage of Angelou leading to their collapse. Angelou gets married to people who are of different cultures and philosophies. As it would be recalled in her narratives, long before she comes of age and thinks of settling down with a man, Angelou mentions some of the fantasies she forms in her mind about the kind of wife she hopes to be. Lupton explains that Angelou's marriages collapse because they both do not meet the demands of her fantasy. It is only when she comes face-to-face with reality that she realizes that in real life most of the fantasies we create do not meet our expectations.

Bloom (1994) shares quite a related view though he looks at it from a different angle. Bloom expresses his views on the non-attainability of freedom and independence by women in oppressive relationships with intolerant and racist individuals. He explains that since Angelou fantasizes about marrying a man who will hold her in high esteem, respect her views and give her much authority in the household, it would have been expected that she would be happy when she makes these choices of marrying Tosh Angelos and Vusi Make. These fantasies, according to Bloom, become unattainable because of the racial and intolerant tendencies that Angelou's two husbands display during their marriage to her. In reality, it is true that Angelou has some expectations for her marriage and to a very large extent, because she does not achieve these expectations, she finally realizes her dissatisfacti on in both marriages so they collapse. 


\section{The SubJect of Marriage in ANGelou's Autobiographies}

The study critically highlights Angelou's marital role-play and mentions how she excels through thick and thin in this enterprise of survival as part of her assiduous search for an identity. This study seeks to explore Angelou's search for self-knowledge and fulfillment through marriage. The study reveals the discrepancy between her fantasy of marriage and the actual experience such that despite her expectations, marriage fails to bring stability to Angelou's life. The study investigates how Angelou's marital experiences in life become a threshold of rediscovery of herself and her son on one hand, and on another, the male counterparts she comes into intimate marital relationships with.

As a young teenage girl and mother, she discovers that being independent would enable her to search and finally find that identity, which would make her know who she is, make others know who she is and rather than inviting their sympathy for her unfortunate predicament, arouse their admiration and support in every way possible. For Angelou's experiences as a married woman, it is evident that she moves from one marital relationship to another without any stability whatsoever. Angelou, as an individual fantasizes of a marriage without blemish and boredom. However, in all the marriages she contracts, she does not get the blissfulness she wishes to experience. It can be said that the movement of Angelou from one marriage to another plainly unveils her lack of fulfillment and lack of happiness that she has been fantasizing about since her childhood. This need for a husband is one that she believes would give her and her son an identity that would enable her to call herself independent, selfreliant and above all, a responsible and respectable individual in her society. Angelou's fantasy of marriage and the actual experience that she goes through in marriage do not in any way match.

\section{Marriage to Tosh Angelos and Vusumzi MaKe}

As it would be recalled, the first contact of Angelou with a man started with her mother's live-in boyfriend, Mr. Freeman who rapes Angelou at a very tender age. We also learn that the lovemaking between Angelou and the good-looking teenage neighbour boy who impregnates her was not a passionate one. The very young Angelou often fantasized about growing up to be a responsible housewife. Angelou in Singin' and Swingin' and Gettin' Merry like Christmas describes how even at age nineteen, her life turned towards the acquisition of more than the basic needs of life. Her romantic fantasies, which were influenced by Hollywood movies and lyrics from popular blues music and jazz, are confronted with reality when, in 1949 she marries her first husband Tosh Angelos, a Greek native. When she marries Tosh, she begins to nurture and have belief in the aggressive notion that "marriage would give (her) a world free from danger, diseases and want" (Singin' and Swingin' and Gettin' Merry like Christmas). Quite soon into the marriage, she discovers that real life offers no such guarantee. As a housewife, she describes herself in the third volume of her autobiography, Singin' and Swingin' and Gettin' Merry like Christmasas:

"Legally a member of that enviable tribe of consumers whom

security made fat and butter and whom no circumstances considered

living by bread alone, because their husbands brought home the bacon"' (p33)

However, Tosh Angelos as the head of the household expects her to relinquish the idea of participating periodically and regularly in the activities of the Black Church, and of course, her black folks and friends. This development in the life of Angelou helps to throw more light on the theme of identity. The reason is simple to explain. This is a young woman in search of home and identity for herself and her son. This identity incorporates anything that would be within her wildest dreams and expectation, happiness in her daily life, freedom to express herself freely, and freedom to associate herself with any group at all irrespective of its religious, political and socio-economic worldview, happiness in her marriage, among several others. This position of Tosh Angelos is anything but an imaginary barricade that seeks to limit the happiness and blissful adventures that Angelou seeks to pursue in life.

Angelou's husband, Tosh Angelos is a very private person and an atheist as well; hence he undermines the role of the black church in his wife's life. As a member of an oppressed group, Maya Angelou values her spiritual life very much but Tosh, her husband does not need that. As it would be recalled, Angelou had been brought up to understand the importance of the church in a man's life by her grandmother, Momma Henderson and for that matter, God in the life of human beings. Momma Henderson, her paternal grandmother whom she grows up with instilled this discipline in her and that she (Angelou) would not let go. It is an identifiable mark or bond between her and her grandmother, 
Momma Henderson. It is relevant to appreciate the fact that Tosh Angelos is a white man who enjoys racial and gender privileges and so, does not appear to understand the importance of religious faith to his wife Angelou.

It is again important to explain Angelou's obsession with her religious faith, and for that matter the black church. Her presence in the black church and her association with her fellow black men and women give her a sense of belonging. Many blacks in America associate themselves with religious groups so that they feel accepted and identified within the group. It is this sense of being identified as a member of the black church, and for that matter, the black community that Angelou wanted. Angelou narrates in the autobiography that she could not just resist the happiness she feels within herself anytime she visits the black church; hence she steals time away from Tosh to go and worship with the black church in the community. She mentions how earnestly she steals time away treacherously to go having fellowship with her folks because identifying herself with the black church, in her own estimation, makes her feel happy being with her people, race, and her kinsmen and women.

Quite ironically, Angelou's association with the black church becomes one of the main reasons for the break-up of her marriage with Tosh Angelos, her first husband. According to Shapiro (1994), Angelou "regarded the church as a defining element of her black heritage that she did not wish to relinquish". (p87) This goes a long way to explain how paramount the issue of identifying herself with her fellow black Americans is to her. Angelou knows that she has no other family other than her fellow blacks. Whether she likes it or not, her fellow blacks are the same hospitable people she has always known, and they are very accommodating such that they are ready to help her out of any unfortunate situation that she finds herself in. This is displayed openly in the fact that despite her obsession with a stable marriage life, Angelou sees hers to Tosh break down before her very eyes due to some very petty squabbles and the religious intolerance on the part of Tosh Angelos. Before Angelou's marriage with Tosh finally collapses, she compromises a lot of herself and puts up with her husband Tosh's demands no matter how unpleasant those demands are to her. Obviously, it is clear that Angelou is ready to live the marriage dream she had been obsessed with to the fullest. However, to some extent, she contributes to the collapse of her marriage to Tosh in 1952 because she surrenders all of her independence to Tosh. As prescribed in most women's magazines, which Angelou had read, she had been a near-perfect a wife to her husband as far as possible.

Despite all these, her husband, Tosh cannot bear the restrictions of this ideal nuclear family structure, which he has created any more than he can bear the strain of being part of an inter-racial marriage in the early 1950's. Angelou reveals in Singin' and Swingin' and Gettin' Merry like Christmas that she actually learns a lesson in life after her marriage collapses; that she should always be focused and learn to be independent, and not allow her life to be solely dependent on a man. She actually makes this resolution in her life when she realizes that the novelty of the marriage with Tosh had worn off, leaving her and her son with little stability. Angelou herself confesses that she became, as it were: "a saner, healthy person than the young, greedy girl who has wanted a man to belong to' (p51)

After the marriage falls on the rocks, Angelou critically comments on all that had happened during her short married life, and one very distinguishing thing that can be made up of her authorial commentary is that Angelou felt maturer and very open-minded than even before. She realizes that everybody makes a mistake at one point in his or her life mostly through youthful exuberance and anxiety for experience and adventure. This education that Angelou sees herself going through goes a long way to open up her mind to knowing more about herself. To a very large extent, it is this lesson of life that seriously rekindles the spirit of her relentless search for her identity. Angelou becomes this positiveminded young girl who is divorced. She makes it her belief that she can do better in life, probably in her next marriage to learn more about life. Obviously, one then becomes aware of the reasons for the earlier comment made about her (Angelou's) movement from one marriage to another that it helps to bring sanity and development and education to her life.

On yet another platform, a very serious discussion can also be raised concerning Angelou's ideal of a glamorous Hollywood fantasy marriage. It can be concluded that her fantasy reflects her mother, Vivian Baxter Johnson's influence on her, even though she (Angelou) would not mostly accept this. Casting one's mind back, readers learn how Angelou becomes influenced by the glamour and beauty of her mother when young Angelou meets her after a four-year period of separation. Angelou herself confesses in I Know Why the Caged Bird Singsthat she "...had never seen a woman as pretty as she who was called my 'mother"'(p112). 
Angelou, as a writer of her own life story, reveals that her mother, Vivian, lives her life as if she were wealthier than she actually is. Vivian Baxter Johnson works in gambling salons, but lives as though she is a movie star. The reality is that, when Angelou comes to know her mother, she can only compare her to a movie star, who she (Vivian Baxter Johnson) is not, and an enchanting Blues music singer who attracts men to herself, which she actually does in a manner that makes her more than the average mother. Laying stress on this connection between Vivian Baxter Johnson and the movies, Angelou recalls her early experiences at the cinema in which Kay Francis, a white actress, who closely resembled Angelou's mother, Vivian, starred. In the first autobiography, I Know Why the Caged Bird Sings, Angelou herself writes that when viewing one movie:

"I laughed too, but not at the hateful jokes (the movie)

made on my people. I laughed because, except that she

was white, the big movie star looked just like my mother.

Except that she has a big mansion with a thousand servants,

she lived just like my mother. And it was funny to think of

the white folks not knowing that the woman they were adoring

could be my mother's twin, except that she was white and

my mother was prettier. Much prettier. The movie star made

me happy. It was extraordinary good fortune to be able to give

up one's money and go see one's mother whenever one wanted." (pp 118-119)

It is relevant to declare that the strong impression that Angelou forms as a child makes it easy to see why she wanted to be a movie star. It is Angelou's mother, Vivian Baxter Johnson who encourages Angelou to study dance and drama from the very beginning. Vivian Baxter Johnson, therefore, takes the initiative to teach Angelou her first dancing steps and the art of body movement in a bar. Ironically, Angelou makes a total comparative study of her mother's lifestyle and the ordinary simple one and realizes that her mother's beauty and blues lifestyle that she wanted to pass on to her is highly competitive. She comes to the full realization that she cannot cope with such a lifestyle. The reality on the ground is that, after Angelou makes the comparison, she acknowledges that she (Angelou) is ugly and feels often neglected and inferior. However, despite everything, her mother's competitive lifestyle, some of which she struggles to copy and others which she relentlessly rejects, becomes her ticket to success and one that ultimately leads to the beginning of her writing career. Angelou rejects some of Vivian Baxter Johnson's maternal and marital practices. For instance, unlike her mother, Vivian who rejected her two children, Angelou is very protective of her child. When Angelou loses both husbands too, unlike Vivian her mother who chooses to stay with live-in boyfriends who help in her upkeep and payment of her domestic bills, Angelou decides to stay alone to struggle to fend for herself single-handedly, and train her only son, Guy Johnson.

On another level, Angelou perseveres to live her life as if nothing had happened to her after her first marriage to Tosh Angelos breaks down. It is very important to say that Angelou's second marriage to Vusi Make also helps her to rediscover her true self and identity in very many ways. It has been noted earlier that her movement from one marriage to another is a sort of education for her since she learns more about marriage, women, men, her fellow black Americans and other Africans as a whole. Angelou, therefore, continues to narrate her experiences with Vusi Make, who happened to be a black South African Political activist.

Vusi Make becomes the second husband of Angelou. When she meets him, she is engaged to a divorced black American bail bondsman by name Thomas Allen. During this time Maya Angelou had assumed a social role as a radical Civil Rights activist, a fundraiser and the Northern Coordinator for the Southern Christian Leadership Conference (SCLC), which is an organization founded by Dr. Martin Luther King Jr. Thomas Allen realizes how desperate she is to marry him. This is reflected in Angelou's own words when she narrates how she goes about entertaining the idea of straightening her hair and wearing pretty hats with flowers and gloves so she can look like an attractive, marriageable material and potential homemaker for Thomas Allen, instead of the non-traditional career woman she really is. Angelou now learns a lot of lessons in life and becomes intelligent. Angelou, during this time, does not appreciate that idea of living in a marriage where conversation is limited to her "shouting" in the bedroom and her man's "grunting" at the dining table. What this really implies is 
that although Angelou is fully aware of the fact that her boyfriend, Thomas Allen wants only sex and good food from her, she is prepared to consider that as sufficient, as long as she has "a husband." Obviously, this idea that she creates as far as her relationship to this boyfriend of hers was concerned was just not the best for her. When she meets Vusi Make, however, she sees in him a more suitable suitor and she marries him, so that it becomes another very hasty decision by her in the area of marriage. Angelou's mother, Vivian Baxter Johnson, advises her (Angelou) against marrying Make because she (Vivian) feels he is a total stranger to the culture of the Black American lifestyle and society. Left to Vivian Baxter Johnson alone, Angelou would marry Thomas Allen, the bail bondsman because she believes Angelou is more familiar with him before the appearance of the freedom fighter, Vusi Make.

The theme of the clash between the fantasies of marital bliss versus the real experience of marriage is fully developed when Angelou gets married to Vusi Make. Angelou narrates how she initially felt mature when she gets the divorce from Tosh Angelos. She reveals that she gets very much educated about the meaninglessness of romantic bliss and how destructive it can be to the person fantasizing about it if it does not become a reality. It becomes rather very discouraging when Angelou still holds on to this same concept of romantic bliss even in her second marriage. Angelou's youthful exuberance may have accounted for this situation. This is because the impression one gets after reading through the pages that tell of the experiences of her second marriage is that Angelou had learnt no lesson at all from all that happened to her when she gets married to Vusi Make. It is, however, important to realize that the second experience, though quite disappointing just like the first, and which could have been avoided if Angelou had made it a point to change certain thoughts based on fantasy, strengthens her in her learning process and her search for identity. As it has been noted earlier, fantasy dominates Angelou's second marriage. Angelou could have avoided the second marriage if she had eschewed those fantasy thoughts of the Hollywood portrayals of romance, Africa (because Vusi Make promises to take her to Africa, the native land of the coloured people) and, of course, the lifestyle of ease and glamour that her mother, Vivian Baxter Johnson pursues. The following passage from the fourth narrative text in the autobiography, The Heart of a Woman, clearly illustrates what actually influences Maya Angelou to marry the South African freedom fighter, Vusi Make:

"At the dining table, he spread before me the lights and

shadows of Africa. Glories stood in thrilling array. Warrior

queens, in necklaces of blue and white beads, led armies

against marauding Europeans. Nubile girls danced in

celebration of the victories of Shaka, the Zulu King." (p150)

The above passage clearly illustrates the fantasies, which ultimately drive Angelou into marrying Make. As it had been noted earlier, when she confesses that she became maturer and wiser after her disappointment by Tosh in their marriage, one would have expected that Angelou would be more careful and extra vigilant and that she would never again rely on romantic fantasies when she finds herself on the marriage market. Unfortunately, she jumps into the arms of a man she hardly knows because she was still in the school of life learning about the intricacies of being a mature human being, an independent woman, a responsible woman and a married person. In these episodes of her married experiences, the theme of the search for stability is fully developed.

The movement of Angelou from one marriage to another and yet, gaining no stability whatsoever can be given a psychological explanation. It is the view of this study that one reason why Angelou gets married to both Tosh Angelos and Vusi Make at different times of her life is her zeal to gain security for herself and her son. Psychologically, Angelou's fear of having no future security has been a long standing one which she has had since childhood when her parents got divorced and still haunts her. Angelou thus harbours the hope that getting married will drive away that fear and give her and the son that future security she had long hoped for. It is unfortunate that she realizes too late that marriage cannot give her that security she had long hoped for.

Another psychological explanation that can be given to the reason why Angelou kept moving from one marriage to the other is that the early divorce of her parents during her formative years created a vacuum of absence of a father in Angelou's life which she thought a husband could fill. Since psychologically she yearned for a father's love, she thought meeting Tosh and later Vusi would 
enable her to experience a father's love and care through them. Unfortunately for her things do not move the way she wanted and the marriage to each of the two men collapses.

Angelou's second husband, Vusi Make has some attitudinal similarity to Tosh Angelos, her first husband. They both expected Angelou to confine all her activities to the home and not outside the home. However, the difference between them is that Vusi Make seems to demand that a lot more of Angelou's energy be spent on work in the home, while Tosh Angelos would not mind Angelou combining a few jobs outside the home with the chores at home. The end result of it all is that, in reality, Angelou becomes spiritually starved in her marriage to Tosh Angelos since he is an atheist, and to Vusi Make, Angelou becomes physically overworked during their marriage.

Vusi Make, according to Angelou's own revelation in her narration, supervises and thoroughly inspects her house cleaning to ensure that she reaches every little dirt under their bed and has removed every bit of dirt from almost every surface in the household. It reaches a point that Angelou reveals how frustrated she becomes and so she writes in The Heart of a Woman how she felt. She wrote thus:

"I wanted to be a wife and to create a beautiful home to make

my man happy, but there was more to life than being a diligent

maid with a permanent pussy". (p168)

This confession that Angelou critically makes is indeed very important in the assumption that she is really learning a very serious lesson in her life. This rings a bell to her readers that she is gradually climbing up the maturation tree or ladder. The daily hectic routine of Angelou is described as very daunting. She critically gives this description in very clear terms in the following terms in The Heart of a Woman:

"It seems to me that I washed, scrubbed, mopped, dusted

and waxed thoroughly every other day.... "I wiped down

the walls, because dirty finger prints could spoil his day,

and ironed his starched shirts...' (p166)

Angelou does not stop there but then continues her description to show how intense her daily chores were so that her readers would realize the impression she sought to create further about the great amount of physical exhaustion through which she went daily. In The Heart of a Woman, she continues thus:

"Each meal at home was a culinary creation. Chicken Kiev and

feijode, Eggs Benedict and Turkey Tetrazzini. A good woman put

ironedshirts on the bed and matched the toilet paper to the colour of the

bathroom tile. I was unemployed but I had never worked so hard

in all my life." (p166)

With all these expectations from Vusi Make, one would expect that he may do what is definitely expected of him: providing for Angelou's every need. Angelou definitely expected her husband, Vusi Make, to meet his side of the bargain by providing for her and her son. It is very ironical however, that Vusi Make is not a good provider. As a political activist, he has an unstable income which entirely depends upon the aids and donations from sympathetic sponsors. Despite these, he rather desires an opulent and wealthy lifestyle that he cannot afford. Vusi Make, according to our narrator who has first-hand information about this man, has an insatiable taste for expensive furniture and classy décor. This lifestyle of Vusi Make rather disgracefully lands his family into huge debts and embarrassment. Angelou finally discovers that Make with all his promises of excitement and exotic pleasure is neither faithful nor reliable; he is not capable of supporting them. Angelou on seeing and realizing this, quickly learns a lesson again and confidently asks for a divorce. Angelou realizes that her second marriage did not give her the joy she envisaged. Vusi Make's unreliable attempt to restrict her fails and, therefore, she starts working outside her home, something she knows how to do best. In taking this step, therefore, Angelou can be said to have reawakened her quest for an identity again. To a very large extent, this is the beginning of a long term fixed mentality that Angelou comes up with; to be steadfast against men who promise women "heaven" but deliver nothing. It is possible that the experience Angelou had with Tosh and later Vusi Make may have propelled her decision to stay single for as long as it makes her stay independent of male oppression and chauvinism. 
Angelou decides to work to make a living for herself and her son in the country of Egypt without relying on Vusi Make who by this time had displayed traits of unfaithfulness and gross incompetence in his duties as a provider for the home. Indeed, except for her short-lived marriage to Tosh Angelos, Angelou has worked ever since she turned the age of sixteen. In reality, Maya Angelou as an industrious woman had always known how much money she had, how to spend it and when to pay her bills. These traits were overshadowed and covered by Vusi Make when she got married to him. Apart from making her a diligent housewife, Vusi Make kept Angelou in the dark about very crucial issues like the finance of the family and so she becomes frustrated and powerless. When she decides to find something economically meaningful to do for herself, finally, she becomes liberated and discovers her true identity: the aspiring, industrious, focused, bold, energetic, and above all, the conscious and determined woman that she really is. It is quite clear from the foregoing that the very forceful, energetic and determined young woman that she is, Angelou makes a rebellious decision to work despite Vusi Make's resistance and this clearly demonstrates how she successfully reclaims her identity and independence. This bold and thoughtful choice she makes to work for herself and child at that point in her life, which of course is very unusual of an independent black woman of her age again illustrates her pragmatism as she faces her life's situation and reality squarely.

It is a fact that because African American women have always worked and bought their own high priced items like cars, furniture, clothes and houses they have always had a strong influence and position in the home. The earnings of their black male counterparts, who most often assume positions in their (African American women's) lives as husbands and partners have not been able to provide more than half of the family's income and expenses. Black women, therefore, have had more working relationships with their husbands than is rather the case with white women (Harris, 2002). This picture of working relationships being painted is sprawled out in Angelou's autobiographies when she finally decides to work for the first time in her second marriage. One thing again is revealed to readers by Angelou in her narrative, especially covering the incidents where Angelou travels to England and later to Africa, specifically Ghana and meets some African women. It comes to her realization that despite Vusi Make's portrayal of Africa and its people to her, African women were not as submissive, mute and powerless as his ideology held them to be. The reason, as Angelou herself reveals, is that in reality, they (African women) have always worked. The various forms of work she categorically mentions include farming in the fields, making arts and crafts items for their own use and for sale, or even entrepreneurs at the market place. It was in fact the patriarchal policy of the colonialists to make men more privileged in education, training and funding programmes that made men more superior and diminished the roles of women in the public sphere (Harris, 2002).

Angelou's second marriage that also comes to an end abruptly goes a long way to prove wrong her fantasy that marriage will bring stability and security of all forms to her doorstep. The short of it all is that Angelou becomes educated about the fact that meeting the "dream man" to settle down within the "dream marriage" will not totally liberate her from all the hardships associated with living in this world as a woman of substance. Those thoughts, as things turned out to be finally, are escapist Hollywood dreams that rarely mature into reality. Indeed, it is Angelou's healthy sense of work ethics and the enterprising spirit that she possesses that altogether enable her to boldly move her to gain the freedom she had long sought for.

It's very important to project in real life that most women unfortunately and regrettably give more value to interpersonal relationships than to their individual work. The end result of it all is that even those women who have achieved economic self-sufficiency are often unable to liberate themselves from oppressive relationship with sexist and racist individuals just like those women who do not work and depend entirely on others for their economic survival (Harris, 2002).

It could be said that Angelou's desire for a good marriage and husband is directly linked to her desire to get a male role model for her son so that he will be an independent, intelligent, and well-rounded son. With her forcefulness and determination as a woman who is bent on establishing an identity for herself, Angelou in her narratives explains how she ends up proving to all, especially her mother, Vivian Baxter Johnson and all her readers that despite the prevailing notions and tags given to divorced women at the time, when she went through these situations, the presence of a father for her son, just like her own situation of growing up without the influence of a biological father, does not always matter necessarily in the consolidation of an identity for oneself. This is because Angelou with devotion and dedication brings up Guy, her son in a very steadfast fashion that does not in any way make him a wayward son. 


\section{SUMMARY}

The study has examined the narratives of the famous African American writer, Maya Angelou. All the narratives are altogether written to drive home a certain point. They all paint the picture through the work of art about the life of a talented artist; an intelligent young girl; her childhood, her ordeals, her adulthood, and almost everything she does by way of finding survival for herself and her growing son. The narratives in autobiography are unified through a number of repeated themes and through the developing character of the narrator.

In this study, an extensive highlight of Angelou's experience of marriage is presented to show how she uses this medium to search for an identity. In fact, the study clearly shows Angelou's marital relationships she experiences as one sure way through which she gets herself educated about certain nuances of life. Angelou records two marital relationships in the volumes of her autobiographies: her marriage to Tosh Angelos and Vusumzi Make. This study mentioned that none of these two marriages worked for her.Critical highlights of her marriage to these husbands have been made in this study.

\section{Conclusion}

The study revealed that initially, Angelou's marriage to Tosh appeared fulfilling and smooth sailing until some few things started going wrong and the marriage fell on the rocks. Two clear reasons were assigned to why the marriage collapsed: first was Angelou's fear that her son's pride in his Black ancestry might be compromised with the presence of a white father. It becomes even clearer that Angelou's insistence on maintaining a Black ancestral pride in her son meant that she was not ready to see all that effort wasted because of her marriage to a white-coloured man. It was a clear display of the theme of search for an identity; secondly, the atheism of her husband, Tosh Angelos quickly facilitated the break-up of that marriage. The study opines that Tosh's atheism manifested itself in his strict directional orders to Angelou not to go worship in the Black church. It was highlighted briefly that Angelou regarded the Black church as a symbolic representation of her recognition of her Black identity. She regarded the Black church as a defining element of her Black heritage that she did not wish to relinquish. The study again concludes that Angelou's love for being among her people to fellowship with them gave her some form of identity, which is not just religious, but social and racial. One other conclusion to draw is that concerning this incident, Angelou's defiance of her husband, Tosh's orders is a clear indication of how she wanted to maintain close ties with members of her race to preserve her racial identity even to the peril of her marriage.

On Angelou's second marriage to Vusumzi Make, the South African freedom fighter, the caution that Vivian Baxter Johnson, Angelou's mother gives to her about marrying someone she barely knows is symbolic. Angelou's mother had actually preferred her to marry Thomas Allen, the bails bondsman, because this is someone she knows. It was recorded that Angelou, with the strong character that she has, preferred to marry the freedom fighter from South Africa, a gross refusal to listen to her mother's counsel. The symbolic representation of the clash between marital bliss versus the real experience of marriage is fully developed with Angelou's marriage to Vusi Make. A judicious exposé of Angelou's immaturity at that point of her life despite her self-claim of having become maturer after her divorce of Tosh Angelos is revealed. About both marriages, the study found out that the two men have something common about them, which was the fact that they both undermined the freedom, dignity and independence of Angelou; they failed to realize that she is a woman with a strong identity and a woman who makes a strong impression wherever she went. In the midst of all these underpinnings, the study concludes that Angelou perseveres and frees herself of these two men at different stages of her life. The conclusion drawn from this indicates that marriage fails to bring stability and adequacy to Angelou's life, hence her movement from one marriage to another. Ultimately, she gets divorced to both men and she really learns a lot from her experiences with them.

These two marriages are, therefore, recognized by the study to have served as learning grounds for Angelou, and so, in effect the two husbands used their influence to educate Angelou in her search for an identity. The study concludes finally that Angelou is successful in using the subject of marriage to define her identity as an African-American woman and to serve as an example for emerging women artists. 


\section{REFERENCES}

Abel, E. (ed) "Merging Identities: The Dynamics of Female Friendship in Contemporary Fiction by Women". Signs, 1981

Angelou, Maya. I Know Why the Caged Bird Sings. New York: Random House, 1970.

Angelou, Maya. Gather Together in My Name. New York: Random House, 1974.

Angelou, Maya. Singin' and Swingin' and Gettin' Merry Like Christmas. New York: Random House, 1976.

Angelou, Maya. The Heart of a Woman. New York: Random House, 1981.

Angelou, Maya. All God's Children Need Traveling Shoes. New York: Random House, 1986.

Angelou, Maya. A Song Flung up to Heaven. New York: Random House, 2000.

Angelou, Maya. "Phenomenal Mothers I Have Known.” Ebony. Vol. 59 May 2004.

Baker Jr, H. Modernism and the Harlem Renaissance. Chicago: University of Chicago Press, 1987.

Bloom, H. (ed). Maya Angelou. Philadelphia: Chelsea House, 1999.

Braxton, J. Black Women Writing Autobiography. Chicago: Temple University Press, 1989.

Carr, D. Time Narrative and History. Indiana: Indiana University Press, 1986.

Carby, H. Reconstructing Womanhood. New York: Oxford University Press, 1987.

Collins, P. H. Black Feminist Thought. New York: Routledge, 2000.

Demetrakopoulos, S. "The Metaphysics of Matrilinealism in Women's Autobiography: Studies of Mead's 'Blackberry Winter', Hellman's 'Pentimento', Angelou's 'I Know Why the Caged Bird Sings' and Kingston's 'The Woman Warrior.” In Estelle C. J (ed). Women's Autobiography: Essays in Criticism. Bloomington: Indiana University Press, 1980.

Egan, S. Mirror Talk: Genres of Crisis in Contemporary Autobiography. Chapel Hill: University of North Carolina Press, 1999.

Elliot, J. (ed). Conversations with Maya Angelou. Mississippi: University of Mississippi Press, 1989.

Fowlie, W. "On Writing Autobiography" in Olney J. (ed). Studies in Autobiography. New York: Oxford University Press, 1988 (pp 163 - 170).

Freeman, M. Rewriting the Self: History, Memory, Narrative. London: Routledge, 1993.

Harphram, G. G. "Conversion and the Language of Autobiography" in Olney, J. (ed). Studies in Autobiography. New York: Oxford University Press, 1988 (pp 42 - 50)

Harris, W. Feminist Literary Theory. New York: Routledge, 2002.

Lejeune, P. On Autobiography. (Trans) Minneapolis: University of Minnesota Press, 1989.

Lupton, M. J. "Singing the Black Mother: Maya Angelou and Autobiographical Continuity." Black American Literature Forum, 1990.

Mandel, B. J. "Full of Life Now" in Olney, J. (ed) Autobiography: Essays Theoretical and Critical. New Jersey: Princeton University Press, 1980. (pp 49-72)

Nelson, E. African American Autobiographers: A Sourcebook. (Maya Angelou (1928- ). Greenwood Press, 2002.

Neubauer, C. "Displacement and Autobiographical Style in Maya Angelou's The Heart of a Woman." Black American Literature Forum. 1983.

Olney, J. (Ed). Autobiography Essays, Theoretical and Critical. New Jersey: Princeton University Press, 1980.

O'Neale, S. "Reconstructing the Composite Self: New Images of Black Women in Maya Angelou's Continuing Autobiography". M. Evans, ed. Black Women Writers (1950-1980): A Critical Evaluation. Anchor Press: Doubleday, 1984.

Pascal, R. Design \& Truth in Autobiography. London: Routledge \& Kegan Paul, 1960.

Shapiro, M. Maya Angelou. New York: Chelsea House, 1994.

Vermillion, M. "Re-embodying the Self: Representations of Rape in 'Incidents in the Life of a Slave Girl' and 'I Know why the Caged Bird Sings."' Biography. Vol. 15, Summer 1992. 